\title{
ANALISIS ELASTISITAS PRODUKSI PADI DI PROVINSI JAWA TIMUR TAHUN 2007-2015
}

\section{Pradityo Fahril Arrahman*, Idah Zuhroh}

Program Studi Ekonomi Pembangunan, Fkaultas Eknomi dan Bisnis, Universitas Muhammadiyah Malang, Jl.Raya Tlogomas No.246 Malang, Indonesia

* Corresponding author: fahrilpradityo@gmail.com

\section{Artikel Info \\ Article history: \\ Received 15 August 2019 \\ Revised 16 September 2019 \\ Accepted 05 December 2019 \\ Available online 15 February \\ 2020}

Keyword: Land area; labor; rice plant production

JEL Classification

E23; J01; Q24

\begin{abstract}
The purpose of this study is (1) to find out how the effect of land area and labor of the agricultural sector on rice production in East Java Districts and (2) to find out how the differences between productivity strata are related to the influence of agricultural land area and labor on rice production in Districts in East Java Province. The analytical tool used is panel data regression which is then tested by hypothesis $F$ test, $t$ test and coefficient of determination (R2) at the error rate $\alpha=5 \%$. The results of panel data regression with the selected model are Fixed Effect Model showing that the area of land has a positive and not significant effect on rice production with a value of 0.08 and labor has a significant negative effect on rice production with a value of -0.31 . While the coefficient of determination (R2) is 0.94 or $94 \%$. Conclusion for East Java, the highest production strata, medium production strata and low strata production coefficient values of land area and labor variables show less than 1, which means inelastic to rice production.
\end{abstract}

\section{PENDAHULUAN}

Indonesia merupakan sebuah negara agraris dimana pertanian memiliki peranan penting pada perekonomian nasional. Hal ini ditunjukkan dengan banyaknya tenaga kerja maupun penduduk yang bermata pencaharian di sektor pertanian (Mubyarto, 2007). Sektor pertaniaan berperan penting karena memberikan kontribusi cukup besar dalam pendapatan nasional, namun beberapa tahun terakhir sektor pertanian menjadi kurang produktif meskipun demikian tetapi sektor pertanian memiliki peranan penting dalam penyerapan tenaga kerja dan penyediaan pangan. Dalam proses produksi sub sektor pertanian memerlukan berbagai masukan (input), seperti bibit, pupuk tenaga kerja, lahan, irigasi, modal dan lain sebagainya. Masukan tersebut menghasilkan keluaran (output) seperti padi, jagung dan komoditas lainya yang merupakan hasil di sub sektor pertanian.(Kholis \& Faisal, 2017). Sebagian besar para petani di Indonesia dapat digolongkan ke dalam peasant atau subsistence yaitu petani yang mempunyai lahan sempit (kurang dari 0,5 ha) dan memanfaatkannya untuk kebutuhannya sendiri (Novianto \& Setyowati, 2009).

Berdasarkan data Kementrian Pertanian tahun 2017 (tabel 1), Provinsi Jawa Timur disebut sebagai lumbung padi di Indonesia, dimana Jawa Timur sendiri menempati urutan pertama penghasil produksi padi diantara provinsi yang lainnya. Provinsi Jawa Timur merupakan wilayah yang mempunyai cukup banyak lahan pertanian dalam hal ini padi menjadi agenda penting yang harus dibahas dalam setiap tahunnya. Upaya dalam pencapaian produksi padi harus sangat diperhatikan dimana pertanian menghadapi berbagai permasalahan seperti luas lahan untuk aktifitas pertanian semakin menyempit, konsumsi masyarakat yang terus. Rata-rata ketergantungan pangan hanya 
berfokus pada satu komoditi saja yaitu padi atau beras hal ini dapat menyebabkan rawan terjadinya gagal panen. Sektor pertaniaan dalam produksinya memiliki beberapa indikator seperti luas lahan, tenaga kerja sektor pertanian, modal, penggunaan bibit dan lain-lainya. Proses produksi akan bisa berjalan jika indikator tersebut sudah terpenuhi, karena masing-masing indikator memiliki fungsi yang berbeda-beda namun terkait satu sama lain. Masukan indikator tersebut menghasilkan keluaran yaitu padi.

Tabel 1. Produksi Padi Tertinggi Pada 10 Provinsi Di Indonesia

\begin{tabular}{lc}
\hline \multicolumn{1}{c}{ Provinsi } & Produksi (Juta Ton) \\
\hline Jawa Timur & 13,1 \\
Jawa Barat & 12,5 \\
Jawa Tengah & 11,4 \\
Sulawesi Selatan & 6 \\
Sumatera Utara & 5,1 \\
Sumatera Selatan & 4,8 \\
Lampung & 4,3 \\
Sumatera Barat & 2,8 \\
Aceh & 2,7 \\
Kalimantan Selatan & 2,4 \\
\hline
\end{tabular}

Sumber : Kementrian Pertanian 2017

Dari gambar 1, diketahui bahwa pertumbuhan produksi padi di Provinsi Jawa Timur mengalami fluktuatif dimana pada tahun 2008 mengalami kenaikan sebesar $11,41 \%$ dari 0,59\% pada tahun 2007. Pada tahun 2009 mengalami penurun sebesar 7,49\%. Pada tahun 2010 mengalami penurunan sebesar 3,42\%. Pada tahun 2011 mengalami penurunan sebesar $-9,17 \%$. Pada tahun 2012 mengalami kenaikan sebesar 15,34\%. Pada tahun 2013 mengalami penurunan sebesar $-1,22 \%$. Pada tahun 2014 mengalami kenaikan sebesar 2,89\%. Pada tahun 2015 mengalami kenaikan kembali sebesar 6,11\%.

\section{Gambar 1. Grafik Produksi Padi Provinsi Jawa Timur Tahun 2007-2015}

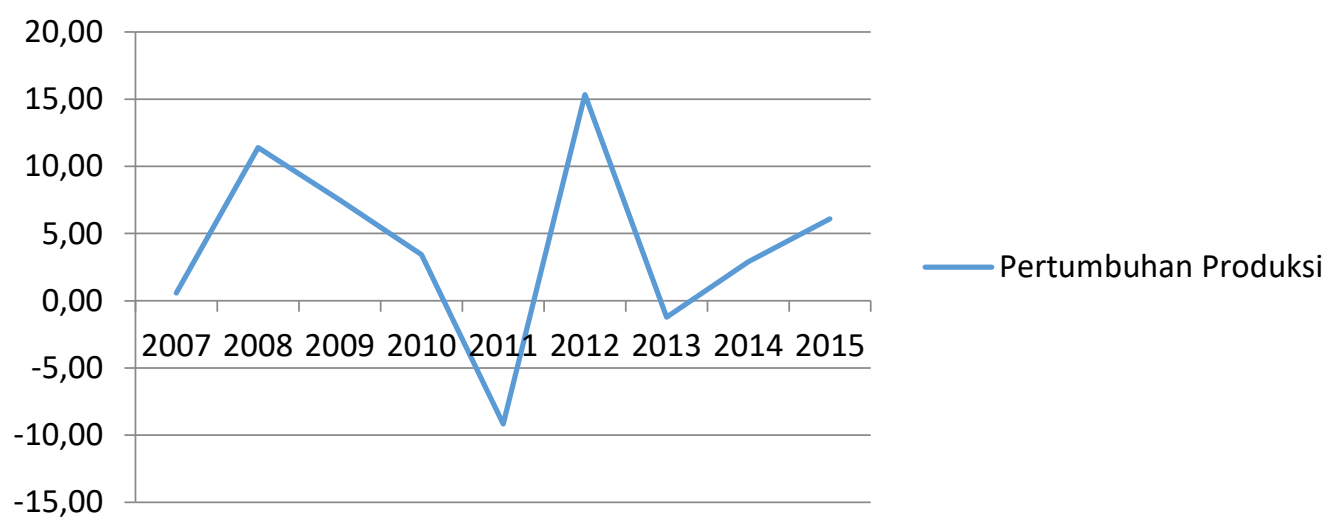

Sumber : BPS Jawa Timur, Diolah 2019

Peranan sektor pertanian untuk meningkatkan kesejahteraan masyarakat penjelasannya sebagai berikut: 1) Sektor pertanian pada perdesaan diharapkan akan mampu membuka lapangan pekerjaan baru untuk mengatasi pengangguran, dengan hal tersebut sektor pertanian akan bisa menjadi penopang utama pada perekonomian di Indonesia. 2) Sektor pertanian pada 
perdesaan juga dapat memberikan kebutuhan pokok dalam hal pangan untuk melemahkan ketergantungan impor pada negeri lain. 3) Peran sektor pertanian ini ialah untuk mendorong ekspor dengan memberikan kualitas produksi petani dengan baik(Setiawan \& Soelistyo, 2017). Komoditas pertanian yang menjadi mayoritas umum bagi masyarakat ialah tanaman padi. Tanaman padi memiliki potensi yang lebih baik dari komoditas lainnya dan memegang peranan yang cukup penting bagi perekonomian nasional, kebutuhan pokok manusia dalam hal pangan pada umumnya mengkonsumsi nasi sebagai makanan sehari-hari. Oleh karena itu para petani menanam tanaman padi untuk mencari pendapatan(Manggala \& Arfida 2018). Pertumbuhan ekonomi menunjukkan peningkatan dalam produksi barang maupun jasa dalam suatu perekonomian, sehingga pertumbuhan ekonomi ini merupakan salah satu indikator penting di dalam melakukan suatu analisis pembangunan ekonomi(Ridlo \& Susilowati, 2018). Fungsi produksi merupakan hubungan teknis antara faktor produksi (input) dengan hasil produksi (output). Faktor produksi merupakan hal yang mutlak dalam proses produksi karena tanpa faktor produksi kegiatan produksi tidak dapat berjalan(Nuraini, 2013). Disisi lain dengan semakin meningkatnya jumlah penduduk membawa konsekuensi semakin bertambahnya jumlah pencari kerja dan angka pengangguran, semakin meningkatnya kebutuhan masyarakat dan meningkatnya angka kemiskinan serta terjadinya kesejangan pendapatan dimasyarakat yang tidak merata, hal ini merupakan dorongan bagi pemerintah dan penyiapan lahan maupun untuk pengadaan sarana produksi yang dibutuhkan sehingga keuntungan petani meningkat(Achmad, 2014).

Jumlah manusia akan meningkat secara eksponensial, sedangkan usaha pertambahan persediaan pangan hanya dapat meningkat secara aritmatika, sehingga akan terjadi sebuah kondisi di mana dunia akan mengalami kekurangan pangan

akibat pertambahan ketersediaan pangan yang tidak sebanding dengan pertambahan penduduk(Aryanto \& Sudarti, 2017). Tujuan penelitian ini yaitu untuk mengetahui bagaimana pengaruh luas lahan dan tenaga kerja sektor pertanian terhadap produksi padi pada Kabupaten di Jawa Timur dan untuk mengetahui bagaimana perbedaan antar strata produktivitas terkait pengaruh luas lahan dan tenaga kerja sektor pertanian terhadap produksi padi pada Kabupaten di Provinsi Jawa Timur.

Menurut(Neonbota \& Kune, 2016) melakukan penelitian dengan judul "Faktor-Faktor Yang Mempengaruhi Usahatani Padi Sawah Di Desa Haekto Kecamatan Noemuti Timur". Variabel yang digunakan antara lain : luas lahan, benih, pupuk, pestisida, tenaga kerja, pengalaman usahatani, pendidikan dan modal. Hasil analisis menunjukkan bahwa variabel positif dan signifikan adalah variabel pupuk, tenaga kerja dan modal. Sedangkan variabel luas lahan, pengalaman, benih dan pendidikan berpengaruh tidak nyata terhadap produksi usahatani padi sawah. Menurut(Triyanto, 2006) melakukan penelitian yang berjudul "Analisis Produksi Padi Di Jawa Tengah". Penelitian ini bertujuan untuk mengetahui pengaruh input luas lahan, tenaga kerja, benih, pupuk dan pompa air terhadap produksi padi di Jawa Tengah. Hasil penelitian menunjukkan bahwa variabel luas lahan, tenaga kerja, benih dan pompa air berpengaruh positif dan signifikan, namun pupuk bepengaruh negatif dan siginifikan terhadap produksi padi di Jawa Tengah. 
Menurut(Khakim, Hastuti, \& Widiyani, 2013) melakukan penelitian yang berjudul "Pengaruh Luas Lahan, Tenaga Kerja, Penggunaan Benih dan Penggunaan Pupuk Terhadap Produksi Padi Di Jawa Tengah". Data yang digunakan adalah data sekunder dan model yang digunakan penelitian ini yaitu analisis regresi berganda engan metode OLS (Ordinary Least Square). Hasil menunjukkan bahwa secara parsial uji t, luas lahan, tenaga kerja dan pupuk berpengaruh sangat signifikan pada $\mathrm{p}<0,01$. Sedangkan penggunaan benih berpengaruh signifikan pada $\alpha=10 \%$. Menurut(Kartikasari, 2011) "Pengaruh Luas Lahan, Modal Dan Tenaga Kerja Terhadap Hasil Produksi Padi Di Kecamatan Keling Kabupaten Jepara". Data yang digunakan adalah data primer dengan metode pengumpulan data berupa kuisoner dan observasi serta diolah menggunakan SPSS. Hasil menunjukkan bahwa luas lahan, modal dan tenaga kerja berpengaruh secara signifikan terhadap produksi padi.

Adapun relevansi penelitian dari keempat penelitian diatas dengan penelitian yang dilakukan oleh peneliti yakni hampir sama karena adanya kesamaan variabel yaitu luas lahan dan tenaga kerja. Namun, relevansi antara kedua penelitian ini adalah membahas produksi padi. Perbedaan fokus penelitian diatas yaitu tahun dan tempat, dimana keempat penelitian diatas mengambil tempat di Desa Haekto Kecamatan Noemuti Timur, di Jawa Tengah dan Kecamatan Keling Kabupaten Jepara sedangkan peneliti berfokus di Provinsi Jawa Timur.

\section{METODE PENELITIAN}

Penelitian ini menggunakan populasi Jawa Timur yang terdiri atas 29 kabupaten. Populasi 29 kabupaten di stratifikasi berdasarkan produktivitas padi tinggi, sedang dan rendah. Stratifikasi didasarkan pada rata-rata produksi selama 9 tahun di setiap kabupaten. Metode pengumpulan data yang dilakukan peneliti yaitu dengan mengumpulkan data sekunder dari berbagai instansi yang terkait untuk mendapatkan data-data meliputi luas lahan, tenaga kerja sektor pertanian dan produksi padi yang tersedia di BPS Jawa Timur (Badan Pusat Statistik).

Teknik analisis data yang peneliti gunakan dalam penelitian ini adalah analisis regresi dengan menggunakan data panel untuk mengetahui apakah semua variabel bebas (luas lahan dan tenaga kerja sektor pertanian) baik secara simultan dan parsial berpengaruh terhadap variabel terikat (produksi padi). Analisis yang digunakan yaitu menggunakan uji $\mathrm{T}$, uji $\mathrm{F}$, regresi data panel dimana menguji Common Effect (CE), Fixed Effect (FE), Random Effect (RE) serta uji Chow dan uji Hausman.(Damodar, 1987). Berikut tahapan-tahapan yang akan dilakukan :

Rumus persamaan untuk menentukan model yang akan dipakai yaitu sebagai berikut :

$\log Y=\beta 0+\log \beta 1 \mathrm{X} 1+\log \beta 2 \mathrm{X} 2+\mathrm{e}$ 
Sehingga dapat ditentukan rumus persamaan modelnya menjadi :

$\log Y^{*} \quad=\beta 0+\log \beta 1 \mathrm{e}+\log \beta 2$ labor $+\mathrm{e}$

Keterangan :

$\mathrm{Y}^{*} \quad=$ Produksi Padi

B0 $=$ Intercept $/$ konstanta

$\mathrm{B} 1, \beta 2=$ Koefisien regresi parsial

$\mathrm{X} 1=$ Luas Lahan

$\mathrm{X} 2=$ Tenaga kerja sektor pertanian

$\mathrm{e}=$ Standar eror

\section{HASIL DAN PEMBAHASAN}

Provinsi Jawa Timur disebut sebagai lumbung padi di Indonesia, dimana Jawa Timur sendiri menempati urutan pertama penghasil produksi padi diantara provinsi yang lainnya di Indonesia. Provinsi Jawa Timur juga memiliki banyak lahan pertanian dan tenaga kerja sektor pertanian.

Gambar 2. Grafik Luas Lahan pada 29 Kabupaten di Provinsi Jawa Timur tahun 2007-2015 (Hektar)

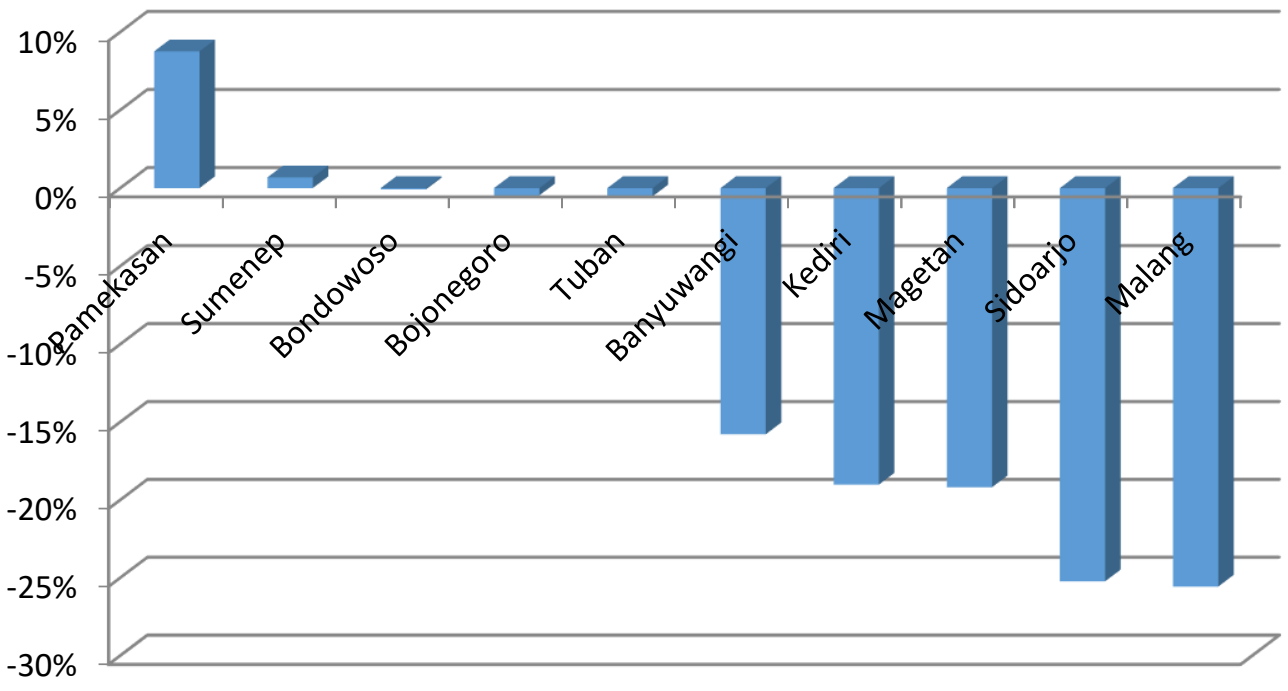

Sumber: BPS Jawa Timur Diolah, 2019

Berdasarkan gambar 2, dapat diketahui bahwa 5 provinsi tertinggi untuk rata-rata pertumbuhan luas lahan meliputi Kabupaten Pamekasan sebesar 9\%, Kabupaten Sumenep sebesar 1\%, Kabupaten Bondowoso sebesar 0\%, Kabupaten Bojonegoro sebesar 0\% dan Kabupaten Tuban yang mengalami penurunan sebesar $-1 \%$. Sedangkan 5 provinsi terendah meliputi Kabupaten Banyuwangi yang mengalami penurunan sebesar $-6 \%$, Kabupaten Kediri sebesar -19\%, Kabupaten Magetan sebesar -9\%, Kabupaten Sidoarjo sebesar $25 \%$ dan Kabupaten Malang sebesar -26\%.

Sedangkan untuk keseluruhan rata-rata pertumbuhan dari tahun 20072015 menunjukkan bahwa rata-rata luas lahan tahun 2007, 2009, 2012 terbilang 
tetap. Tahun 2008 rata-rata luas lahan tertinggi pada Kabupaten Sumenep sebesar 0,23 dengan nilai pertumbuhan 23\% sedangkan terendah pada Kabupaten Banyuwangi yang mengalami penurunan sebesar -0,09 dengan nilai pertumbuhan -9\%. Tahun 2010 pada Kabupaten Pamekasan sebesar 0,21 dengan nilai pertumbuhan $21 \%$ sedangkan terendah pada Kabupaten Sumenep yang mengalami penurunan sebesar $-0,12$ dengan nilai pertumbuhan $-12 \%$. Tahun 2011 pada Kabupan Situbondo sebesar 0,01 dengan nilai pertumbuhan 1\% sedangkan terendah pada Kabupaten Pamekasan yang mengalami penurunan sebesar $-0,04$ dengan nilai pertumbuhan $-4 \%$. Tahun 2013 pada Kabupaten Pamekasan sebesar 0,09 dengan nilai pertumbuhan 9\% sedangkan terendah pada Kabupaten Pacitan yang mengalami penurunan sebesar -0,02 dengan nilai pertumbuhan -2\%. Tahun 2014 pada Kabupaten Sidoarjo sebesar 0,03 dengan nilai pertumbuhan 3\% sedangkan terendah pada Kabupaten Sumenep yang mengalami penurunan sebesar $-0,02$ dengan nilai pertumbuhan -2\%. Tahun 2015 pada Kabupaten Pamekasan sebesar 0,09 dengan nilai pertumbuhan $9 \%$ sedangkan terendah pada Kabupaten Malang yang mengalami penurunan sebesar -0,26 dengan nilai pertumbuhan $-26 \%$.

Gambar 3. Grafik Tenaga Kerja Sektor Pertanian pada 29 Kabupaten di Provinsi Jawa Timur tahun 2007-2015 (Jiwa)

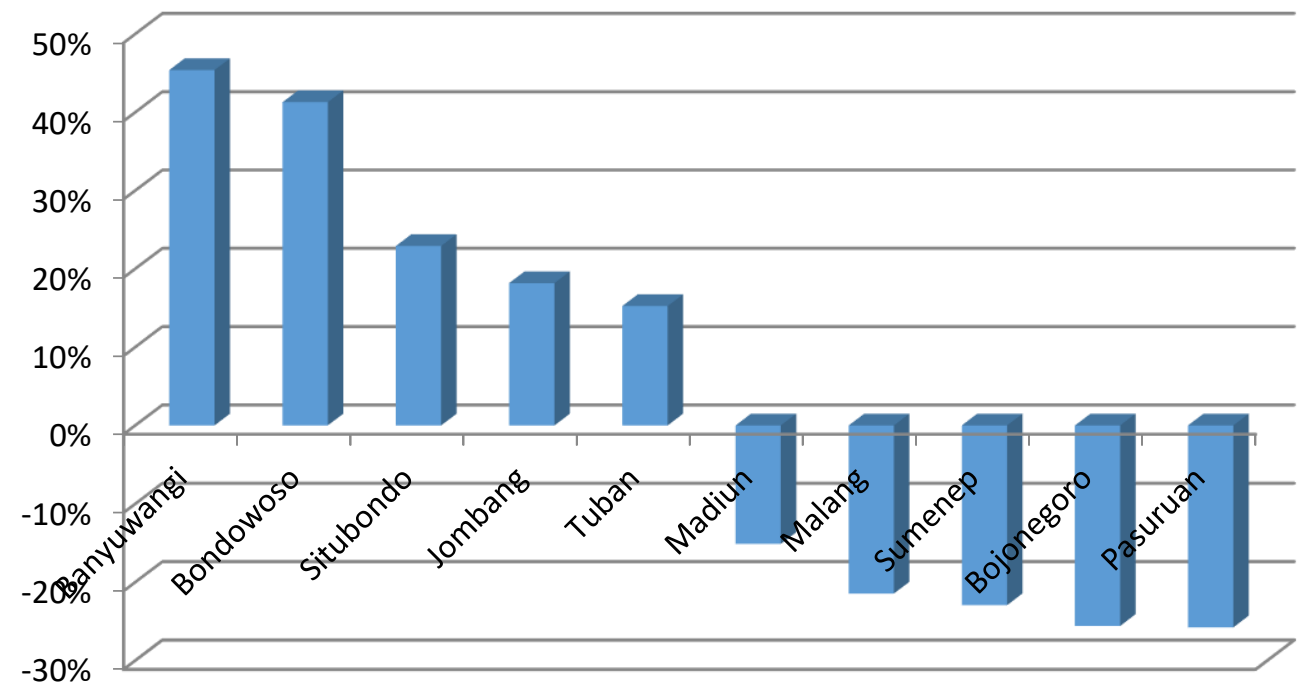

Sumber: BPS Jawa Timur Diolah, 2019

Berdasarkan gambar 3, dapat diketahui bahwa 5 provinsi tertinggi untuk rata-rata pertumbuhan tenaga kerja meliputi Kabupaten Banyuwangi sebesar 45\%, Kabupaten Bondowoso sebesar 41\%, Kabupaten Situbondo sebesar 23\%, Kabupaten Jombang sebesar $18 \%$ dan Kabupaten Tuban sebesar $15 \%$. Sedangkan 5 provinsi terendah meliputi Kabupaten Madiun yang mengalami penurunan sebesar $-15 \%$, Kabupaten Malang sebesar $-21 \%$, Kabupaten Sumenep sebesar -23\%, Kabupaten Bojonegoro sebesar $-26 \%$ dan Kabupaten Pasuruan sebesar $-26 \%$.

Sedangkan untuk keseluruhan rata-rata pertumbuhan tenaga kerja dari tahun 2007-2015 menunjukkan bahwa rata-rata tenaga kerja tertinggi tahun 2007 pada Kabupaten Bondowoso sebesar 0,62 dengan nilai pertumbuhan 62\% 
sedangkan terendah pada Kabupaten Lamongan yang mengalami penurunan sebesar $-0,33$ dengan nilai pertumbuhan $-33 \%$. Tahun 2008 pada Kabupaten Sidoarjo sebesar 0,17 dengan nilai pertumbuhan $17 \%$ sedangkan terendah pada Kabupaten Ngawi yang mengalami penurunan sebesar -0,13 dengan nilai pertumbuhan -13\%. Tahun 2009 pada Kabupaten Sidoarjo sebesar 0,11 dengan nilai pertumbuhan $11 \%$ sedangkan terendah pada Kabupaten Madiun yang mengalami penurunan sebesar $-0,12$ dengan nilai pertumbuhan $-12 \%$. Tahun 2010 pada Kabupaten Probolinggo sebesar 0,04 dengan nilai pertumbuhan 4\% sedangkan terendah pada Kabupaten Tulungagung yang mengalami penurunan sebesar -0,14 dengan nilai pertumbuhan -14\%. Tahun 2011 pada Kabupaten Pamekasan sebesar 0,28 dengan nilai pertumbuhan 28\% sedangkan terendah pada Kabupaten Sidoarjo yang mengalami penurunan sebesar -0,27 dengan nilai pertumbuhan -27\%. Tahun 2012 pada Kabupaten Bangkalan sebesar 0,15 dengan nilai pertumbuhan $15 \%$ sedangkan terendah pada Kabupaten Sidoarjo yang mengalami penurunan sebesar $-0,16$ dengan nilai pertumbuhan $-16 \%$. Tahun 2013 pada Kabupaten Sidoarjo sebesar 0,29 dengan nilai pertumbuhan $29 \%$ sedangkan terendah pada Kabupaten Jember yang mengalami penurunan sebesar $-0,17$ dengan nilai pertumbuhan $-17 \%$. Tahun 2014 pada Kabupaten Madiun sebesar 0,14 dengan nilai pertumbuhan 14\% sedangkan terendah pada Kabupaten Situbondo yang mengalami penurunan sebesar $-0,21$ dengan nilai pertumbuhan $-21 \%$. Tahun 2015 pada Kabupaten Banyuwangi sebesar 0,45 dengan nilai pertumbuhan 45\% sedangkan terendah pada Kabupaten Bojonegoro yang mengalami penurunan sebesar -0,26 dengan nilai pertumbuhan $-26 \%$.

Gambar 4. Grafik Produksi Padi pada 29 Kabupaten di Provinsi Jawa Timur tahun 2007-2015 (Ton)

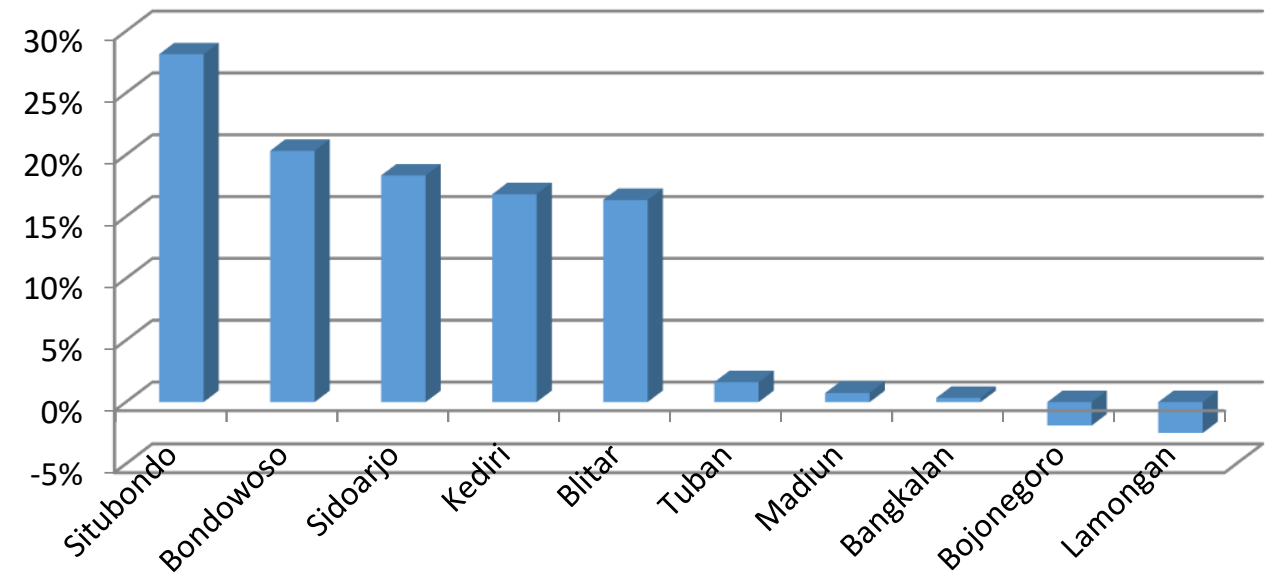

Sumber: BPS Jawa Timur Diolah, 2019

Berdasarkan gambar 4, dapat diketahui bahwa 5 provinsi tertinggi untuk rata-rata pertumbuhan produksi padi meliputi Kabupaten Situbondo sebesar 28\%, Kabupaten Bondowoso sebesar 20\%, Kabupaten Sidorjo sebesar 18\%, Kabupaten Kediri sebesar 17\% dan Kabupaten Blitar sebesar 16\%. Sedangkan 5 provinsi terendah meliputi Kabupaten Tuban sebesar 2\%, Kabupaten Madiun 
sebesar 1\%, Kabupaten Bangkalan sebesar 0\%, Kabupaten Bojonegoro yang mengalami penurunan sebesar $-2 \%$ dan Kabupaten Lamongan sebesar $-2 \%$.

Sedangkan untuk keseluruhan rata-rata pertumbuhan produksi padi dari tahun 2007-2015 menunjukkan bahwa rata-rata produksi padi tertinggi tahun 2007 pada Kabupaten Pamekasan sebesar 0,91 dengan nilai pertumbuhan 91\% sedangkan terendah pada Kabupaten Blitar yang mengalami penurunan sebesar $-0,11$ dengan nilai pertumbuhan $-11 \%$. Tahun 2008 pada Kabupaten Sumenep sebesar 0,42 dengan nilai pertumbuhan $42 \%$ sedangkan terendah pada Kabupaten Pasuruan sebesar 0,03 dengan nilai pertumbuhan 3\%. Tahun 2009 pada Kabupaten Sumenep sebesar 0,44 dengan nilai pertumbuhan 44\% sedangkan terendah pada Kabupaten Pamekasan yang mengalami penurunan sebesar $-0,12$ dengan nilai pertumbuhan $-12 \%$. Tahun 2010 pada Kabupaten Blitar sebesar 0,26 dengan nilai pertumbuhan $26 \%$ sedangkan terendah pada Kabupaten Sumenep yang mengalami penurunan sebesar -0,17 dengan nilai pertumbuhan -17\%. Tahun 2011 pada Kabupan Bangkalan sebesar 0,13 dengan nilai pertumbuhan $13 \%$ sedangkan terendah pada Kabupaten Lamongan yang mengalami penurunan sebesar $-0,28$ dengan nilai pertumbuhan $-28 \%$. Tahun 2012 pada Kabupaten Lamongan sebesar 0,42 dengan nilai pertumbuhan 42\% sedangkan terendah pada Kabupaten Sumenep yang mengalami penurunan sebesar -0,09 dengan nilai pertumbuhan -9\%. Tahun 2013 pada Kabupaten Sumenep sebesar 0,28 dengan nilai pertumbuhan 28\% sedangkan terendah pada Kabupaten Nganjuk yang mengalami penurunan sebesar -0,20 dengan nilai pertumbuhan -20\%. Tahun 2014 pada Kabupaten Ngajuk sebesar 0,16 dengan nilai pertumbuhan $16 \%$ sedangkan terendah pada Kabupaten Pacitan yang mengalami penurunan sebesar $-0,14$ dengan nilai pertumbuhan $-14 \%$. Tahun 2015 pada Kabupaten Situbondo sebesar 0,28 dengan nilai pertumbuhan 28\% sedangkan terendah pada Kabupaten Bojonegoro yang mengalami penurunan sebesar $-0,02$ dengan nilai pertumbuhan $-2 \%$.

Tabel 2. Uji Kesesuaian Model

\begin{tabular}{cccc}
\hline & Uji Chow & Uji Hausman & Keterangan \\
\hline Jawa Timur & 0.0000 & 0.0000 & Fixed Effect \\
Tinggi & 0.0000 & 0.0001 & Fixed Effect \\
Sedang & 0.0000 & 0.0149 & Fixed Effect \\
Rendah & 0.0000 & 0.0449 & Fixed Effect \\
\hline
\end{tabular}

Sumber : Data Diolah, 2019

Hipotesis untuk Uji Chow adalah :

H0 : Common Effect Model

$\mathrm{H} 1$ : Fixed Effect Model

\section{Hipotesis pengujian hausman adalah :}

HO : Random Effect

H1 : Fixed Effect

Berdasakan hasil Uji Chow untuk Jawa Timur maka diperoleh Prob.F $=0,0000$. Nilai tersebut lebih kecil dari $\alpha=0,05$ sehingga diputuskan untuk menolak H0 dan menerima H1. Dengan demikian, dapat disimpulkan bahwa model Fixed Effect lebih tepat digunakan daripada model Common Effect. Berdasarkan Uji Hausman maka diperoleh nilai prob $=0,0000$. Nilai tersebut lebih kecil dari $\alpha=0,05$ sehingga diputuskan untuk menerima $\mathrm{H} 1$ dan menolak 
H0. Dengan demikian dapat dikatakan bahwa model Fixed Effect lebih tepat digunakan daripada model Random Effect. Dari Kedua uji yang dilakukan, maka diambil kesimpulan bahwa model yang paling sesuai adalah model Fixed Effect.

Berdasakan hasil Uji Chow untuk strata produktivitas tertinggi maka diperoleh Prob.F $=0,0000$. Nilai tersebut lebih kecil dari $\alpha=0,05$ sehingga diputuskan untuk menolak H0 dan menerima H1. Dengan demikian, dapat disimpulkan bahwa model Fixed Effect lebih tepat digunakan daripada model Common Effect. Berdasarkan Uji Hausman maka diperoleh nilai prob = 0,0001 . Nilai tersebut lebih kecil dari $\alpha=0,05$ sehingga diputuskan untuk menerima H1 dan menolak H0. Dengan demikian dapat dikatakan bahwa model Fixed Effect lebih tepat digunakan daripada model Random Effect. Dari Kedua uji yang dilakukan, maka diambil kesimpulan bahwa model yang paling sesuai adalah model Fixed Effect.

Berdasakan hasil Uji Chow untuk strata produktivitas sedang maka diperoleh Prob.F $=0,0000$. Nilai tersebut lebih kecil dari $\alpha=0,05$ sehingga diputuskan untuk menolak H0 dan menerima H1. Dengan demikian, dapat disimpulkan bahwa model Fixed Effect lebih tepat digunakan daripada model Common Effect. Berdasarkan Uji Hausman maka diperoleh nilai prob = 0,0149 . Nilai tersebut lebih kecil dari $\alpha=0,05$ sehingga diputuskan untuk menerima H1 dan menolak H0. Dengan demikian dapat dikatakan bahwa model Fixed Effect lebih tepat digunakan daripada model Random Effect. Dari Kedua uji yang dilakukan, maka diambil kesimpulan bahwa model yang paling sesuai adalah model Fixed Effect.

Berdasakan hasil Uji Chow untuk strata produktivitas rendah maka diperoleh Prob.F $=0,0000$. Nilai tersebut lebih kecil dari $\alpha=0,05$ sehingga diputuskan untuk menolak H0 dan menerima H1. Dengan demikian, dapat disimpulkan bahwa model Fixed Effect lebih tepat digunakan daripada model Common Effect. Berdasarkan Uji Hausman maka diperoleh nilai prob = 0,0449 . Nilai tersebut lebih kecil dari $\alpha=0,05$ sehingga diputuskan untuk menerima $\mathrm{H} 1$ dan menolak H0. Dengan demikian dapat dikatakan bahwa model Fixed Effect lebih tepat digunakan daripada model Random Effect. Dari Kedua uji yang dilakukan, maka diambil kesimpulan bahwa model yang paling sesuai adalah model Fixed Effect.

Tabel 3. Fixed Effect Model

\begin{tabular}{cccccc}
\hline & Variabel & Koefisien & Prob & Prob F & R-Square \\
\hline Jawa & Luas lahan & 0.086220 & 0.1438 & & \\
Timur & Tenaga & & & 0.000000 & 0.942215 \\
& Kerja & -0.312116 & 0.0001 & & \\
Tinggi & Luas lahan & 0.491001 & 0.2012 & 0.000000 & 0.876134
\end{tabular}




\begin{tabular}{cccccc}
\hline \multirow{5}{*}{ Sedang } & Tenaga & & & & \\
& Kerja & -0.404431 & 0.0001 & & \\
\multirow{4}{*}{ Rendah } & Luas lahan & 0.057873 & 0.2224 & & \\
& Tenaga & & & 0.000000 & 0.698620 \\
& Kerja & -0.300038 & 0.0027 & & \\
& Luas lahan & 0.752620 & 0.0271 & & \multirow{2}{*}{0.000000} \\
& Tenaga & & & 0.657364 \\
& Kerja & -0.156286 & 0.4543 & & \\
\hline
\end{tabular}

\section{Uji F-Statistik}

Hasil dari uji secara simultan (Uji F), Uji parsial (Uji t) dan koefisien determinasi berganda (R2) dapat ditunjukkan dalam table diatas.

\section{Kriteria pengujian :}

Jika probabilitas $\mathrm{F}$ hitung $\leq \alpha(0,05)$, dimana $\alpha$ merupakan kesalahan yang ditolerir di dalam pengambilan keputusan maka $\mathrm{H} 0$ ditolak dan $\mathrm{H} 1$ diterima.

Jika probabilitas $\mathrm{F}$ hitung $\geq \alpha(0,05)$, dimana $\alpha$ merupakan besarnya kesalahan yang ditolerir di dalam pengambilan keputusan maka $\mathrm{H} 0$ diterima dan $\mathrm{H} 1$ ditolak.

Probabilitas F-statistic adalah sebesar $0,0000 \leq$ nilai probabilitas $\alpha=5 \%$ berarti $\mathrm{H} 1$ diterima yang artinya ada minimal satu dari variabel bebas (luas lahan dan tenaga kerja sektor pertanian) yang berpengaruh terhadap variabel terikat (produksi padi).

\section{Uji t-Statistik}

Kriteria pengambilan keputusan :

Jika probabilitas $t$ hitung $\leq \alpha(0,05)$, dimana $\alpha$ merupakan besarnya kesalahan yang ditolerir di dalam pengambilan keputusan maka $\mathrm{H} 0$ ditolak dan H1 diterima.

Jika probabilitas $\mathrm{t}$ hitung $\geq \alpha(0,05)$, dimana $\alpha$ merupakan besarnya kesalahan yang ditolerir di dalam pengambilan keputusan maka $\mathrm{H} 0$ diterima dan $\mathrm{H} 1$ ditolak.

Berdasarkan hasil uji untuk Jawa Timur diperoleh probabilitas t hitung variabel luas lahan $=0,1438 \geq$ nilai probabilitas $\alpha=5 \%$ maka $\mathrm{H} 1$ ditolak dan H1 diterima yang artinya variabel luas lahan berpengaruh positif dan tidak signifikan terhadap produksi padi pada 29 Kabupaten di Provinsi Jawa Timur. Sedangkan variabel tenaga kerja memiliki probabilitas t hitung sebesar $=0,0001$ $\leq$ nilai probabilitas $\alpha=5 \%$ maka $\mathrm{H} 0$ diterima dan $\mathrm{H} 1$ ditolak yang artinya variabel tenaga kerja berpengaruh negatif dan signifikan terhadap produksi padi pada 29 Kabupaten di Provinsi Jawa Timur.

Berdasarkan hasil uji untuk strata produktivitas tinggi diperoleh probabilitas t hitung variabel luas lahan $=0,2012 \geq$ nilai probabilitas $\alpha=5 \%$ maka $\mathrm{H} 1$ ditolak dan $\mathrm{H} 1$ diterima yang artinya variabel luas lahan berpengaruh positif dan tidak signifikan terhadap produksi padi pada 10 Kabupaten dengan produksi tertinggi di Provinsi Jawa Timur. Sedangkan variabel tenaga kerja memiliki probabilitas thitung sebesar $=0,0001 \leq$ nilai probabilitas $\alpha=5 \%$ maka $\mathrm{H} 0$ diterima dan $\mathrm{H} 1$ ditolak yang artinya variabel tenaga kerja berpengaruh negatif dan signifikan terhadap produksi padi pada 10 Kabupaten dengan produksi tertinggi di Provinsi Jawa Timur. 
Berdasarkan hasil uji untuk strata produktivitas sedang diperoleh probabilitas t hitung variabel luas lahan $=0,2224 \geq$ nilai probabilitas $\alpha=5 \%$ maka $\mathrm{H} 1$ ditolak dan $\mathrm{H} 1$ diterima yang artinya variabel luas lahan berpengaruh positif dan tidak signifikan terhadap produksi padi pada 10 Kabupaten dengan produksi sedang di Provinsi Jawa Timur. Sedangkan variabel tenaga kerja memiliki probabilitas t hitung sebesar $=0,0027 \leq$ nilai probabilitas $\alpha=5 \%$ maka $\mathrm{H} 0$ diterima dan $\mathrm{H} 1$ ditolak yang artinya variabel tenaga kerja berpengaruh negatif dan signifikan terhadap produksi padi pada 10 Kabupaten dengan produksi sedang di Provinsi Jawa Timur.

Berdasarkan hasil uji untuk strata produktivitas rendah diperoleh probabilitas $t$ hitung variabel luas lahan $=0,0271 \leq$ nilai probabilitas $\alpha=5 \%$ maka $\mathrm{H} 1$ diterima dan $\mathrm{H} 1$ ditolak yang artinya variabel luas lahan berpengaruh positif dan signifikan terhadap produksi padi pada 9 Kabupaten dengan produksi terendah di Provinsi Jawa Timur. Sedangkan variabel tenaga kerja memiliki probabilitas t hitung sebesar $=0,4543 \geq$ nilai probabilitas $\alpha=5 \%$ maka $\mathrm{H} 0$ ditolak dan $\mathrm{H} 1$ diterima yang artinya variabel tenaga kerja berpengaruh negatif dan tidak signifikan terhadap produksi padi pada 9 Kabupaten dengan produksi terendah di Provinsi Jawa Timur.

Hasil perhitungan koefisien determinasi (R-squared) untuk Jawa Timur adalah 0,942215. Dimana nilai ini menjelaskan bahwa 94,22\% variabel bebas yang digunakan (luas lahan dan tenaga kerja sektor pertanian) dapat menjelaskan model produksi padi, sedangkan sisanya dapat dijelaskan oleh variabel lain di luar model yang digunakan. Hasil perhitungan koefisien determinasi (R-squared) untuk strata produkvitas tertinggi adalah 0,876134. Dimana nilai ini menjelaskan bahwa $87,61 \%$ variabel bebas yang digunakan (luas lahan dan tenaga kerja sektor pertanian) dapat menjelaskan model produksi padi, sedangkan sisanya dapat dijelaskan oleh variabel lain di luar model yang digunakan.

Hasil perhitungan koefisien determinasi (R-squared) untuk strata produkvitas sedang adalah 0,698620. Dimana nilai ini menjelaskan bahwa $69,86 \%$ variabel bebas yang digunakan (luas lahan dan tenaga kerja sektor pertanian) dapat menjelaskan model produksi padi, sedangkan sisanya dapat dijelaskan oleh variabel lain di luar model yang digunakan. Hasil perhitungan koefisien determinasi (R-squared) untuk strata produkvitas terendah adalah 0,657364. Dimana nilai ini menjelaskan bahwa $65,73 \%$ variabel bebas yang digunakan (luas lahan dan tenaga kerja sektor pertanian) dapat menjelaskan model produksi padi, sedangkan sisanya dapat dijelaskan oleh variabel lain di luar model yang digunakan.

Berdasarkan hasil analisis data menggunakan regresi, maka diketahui pengaruh antar variabel bebas dan terikat. Yaitu pengaruh luas lahan dan tenaga kerja sektor pertanian terhadap produksi padi, sebagaimana berikut :

Tabel 4. Perbedaan Nilai Elastisitas Produksi Padi Setiap Strata Produkvitas

\begin{tabular}{ccc}
\hline Strata Produktivitas & Variabel & Koefisien \\
\hline \multirow{2}{*}{ Tertinggi } & Luas Lahan & 0,491001 \\
& Tenaga Kerja & $-0,404431$ \\
Sedang & Luas Lahan & 0,057873 \\
Terendah & Tenaga Kerja & $-0,300038$ \\
& Luas Lahan & 0,752620
\end{tabular}


Produksi padi dengan nilai koefisien pada setiap Strata pada 29 Kabupaten di Provinsi Jawa Timur, strata produktivitas tinggi mempunyai nilai koefisien dengan varibel luas lahan sebesar 0,491001 dan variabel tenaga kerja sebesar -0,404431 yang berarti inelastis terhadap produksi padi; strata produktivitas sedang mempunyai nilai koefisien dengan variabel luas lahan sebesar 0,057873 dan variabel luas lahan sebesar $-0,300038$ yang berarti inelastis terhadap produksi padi; strata produktivitas rendah mempunyai nilai koefisien dengan variabel luas lahan sebesar 0,752620 dan variabel tenaga kerja sebesar -0,156286 yang berarti inelastis terhadap produksi padi.

Berdasarkan hasil analisis regresi untuk Jawa Timur dapat diketahui bahwa luas lahan berpengaruh positif dan tidak signifikan terhadap produksi padi, sedangkan tenaga kerja berpengaruh negatif dan signifikan terhadap produksi padi. Dengan nilai koefisien luas lahan sebesar 0,086220 Dimana jika terjadi penambahan luas lahan sebesar $1 \%$ maka akan meningkatkan produksi padi sebesar $0,08 \%$ dan tenaga kerja dengan nilai koefisien sebesar $-0,312116$ Dimana jika terjadi penambahan tenaga kerja sebesar $1 \%$ maka akan menurunkan produksi padi sebesar $0,31 \%$.

Berdasarkan hasil analisis regresi untuk strata produktivitas tertinggi dapat diketahui bahwa luas lahan berpengaruh positif dan tidak signifikan terhadap produksi padi, sedangkan tenaga kerja berpengaruh negatif dan signifikan terhadap produksi padi. Dengan nilai koefisien luas lahan sebesar 0,491001 Dimana jika terjadi penambahan luas lahan sebesar 1\% maka akan meningkatkan produksi padi sebesar $0,49 \%$ dan tenaga kerja dengan nilai koefisien sebesar -0,404431 Dimana jika terjadi penambahan tenaga kerja sebesar $1 \%$ maka akan menurunkan produksi padi sebesar $0,40 \%$.

Berdasarkan hasil analisis regresi untuk strata produktivitas sedang dapat diketahui bahwa luas lahan berpengaruh positif dan tidak signifikan terhadap produksi padi, sedangkan tenaga kerja berpengaruh negatif dan signifikan terhadap produksi padi. Dengan nilai koefisien luas lahan sebesar 0,057873 Dimana jika terjadi penambahan luas lahan sebesar 1\% maka akan meningkatkan produksi padi sebesar $0,05 \%$ dan tenaga kerja dengan nilai koefisien sebesar -0,300038 Dimana jika terjadi penambahan tenaga kerja sebesar $1 \%$ maka akan menurunkan produksi padi sebesar $0,30 \%$.

Berdasarkan hasil analisis regresi untuk strata produktivitas rendah dapat diketahui bahwa luas lahan berpengaruh positif dan signifikan terhadap produksi padi, sedangkan tenaga kerja berpengaruh negatif dan tidak signifikan terhadap produksi padi. Dengan nilai koefisien luas lahan sebesar 0,752620 Dimana jika terjadi penambahan luas lahan sebesar 1\% maka akan meningkatkan produksi padi sebesar $0,75 \%$ dan tenaga kerja dengan nilai koefisien sebesar -0,156286 Dimana jika terjadi penambahan tenaga kerja sebesar $1 \%$ maka akan menurunkan produksi padi sebesar $0,15 \%$.

\section{KESIMPULAN}

Kesimpulan yang dapat diambil peneliti dalam penelitian ini adalah hasil dari uji hipotesis mengunakan uji secara parsial (uji t) dan uji simultan (uji F) 
menunjukkan bahwa variabel untuk Jawa Timur, strata produksi tertinggi dan strata produksi sedang variabel luas lahan berpengaruh dan tidak signifikan terhadap produksi padi. Sedangkan variabel tenaga kerja berpengaruh signifikan terhadap produksi padi. Sedangkan untuk strata produksi terendah menunjukkan bahwa variabel luas lahan berpengaruh signifikan terhadap produksi padi dan variabel tenaga kerja berpengaruh tidak signifikan terhadap produksi padi. Jawa Timur, strata produksi tertinggi, strata produksi sedang dan strata produksi rendah nilai koefisien variabel luas lahan dan tenaga kerja menunjukkan kurang dari 1 yang berarti inelastis terhadap produksi padi. Tidak siginifikannya luas lahan disebabkan karena luas lahan semakin lama makin semakin sedikit atau semakin menyempit sedangkan untuk tenaga kerja disebabkan karena tenaga kerja yang kurang produktif dan efisien, meskipun tenaga kerja banyak tetapi jika tidak diiringi dengan produktivitas dan efisiensi maka hasil produksi padi tidak terlalu meningkat.

\section{DAFTAR PUSTAKA}

Aryanto, D., D \& Sudarti. (2017). Analisis Faktor-Faktor Yang Mempengaruhi Pendapatan Buruh Nelayan Di Pantai Sendangbiru Desa Tambakrejo Kabupaten Malang. Jurnal Ilmu Ekonomi. 10 (10), 16-29.

Data.com, K. (2017). Online Data Dictionary. Retrieved July 31, 2019, from https://www.kamusdata.com/daftar-10-provinsi-dengan-produksi-paditerbesar-di-indonesia/

Gujarati, Damodar N., \& S. Zein. 1987. Ekonometrika Dasar. Jakarta: Erlangga.

Jatim.bps.go.id. (2015). Jawa Timur Dalam Angka. Retrieved May 28, 2019, from https://jatim.bps.go.id/publication.html

Junaidi, Zamzami, \& Achmad, E. (2014). Analisis Produksi, Distribusi Pendapatan Petani dan Dampak Program Optimalisasi Lahan Terhadap Produksi Padi Sawah di Kabupaten Muaro Jambi. Jurnal Perspektif Pembiayaan dan Pembangunan Daerah, 2 (1)

Kartikasari, D. (2011). Pengaruh luas lahan, modal, dan tenaga kerja terhadap hasil produksi padi di kecamatan keling kabupaten jepara. Universitas Negeri Semarang.

Khakim, L., Hastuti, D., \& Widiyani, A. (2013). Pengaruh Luas Lahan, Tenaga Kerja, Penggunaan Benih, Dan Penggunaan Pupuk Terhadap Produksi Padi, Jurnal Ilmu-Ilmu Pertanian Mediagro, 71-79.

Kholis, N., \& Abdullah, F. (2017). Faktor-Faktor Yang Mempengaruhi Produksi Padi Di Kabupaten Malang Pada Tahun 2010-2016. Jurnal Ilmu Ekonomi, 1 (1).

Mangala, R., \& Boerochminarni, A. (2018). Faktor-Faktor Yang Mempengaruhi Produksi Padi Di Desa Sumengko Kecamatan Sukomoro Kabupaten Nganjuk. Jurnal Ilmu Ekonomi, 2 (3), 441-452. 
Mubyarto, 2007. Pengantar Ekonomi Pertanian. Jakarta: LP3ES.

Nuraini, Ida. 2013. Pengantar Ekonomi Mikro. Malang: UMM Press.

Novianto, F. W., \& Setyowati, E. (2009). Analisis Produksi Padi Organik Di Kabupaten Sragen Tahun 2008. Jurnal Ekonomi Pembangunan, 10 (2), 267288.

Ridlo, A., \& Susilowati, D. (2018). Analisis Sektor Pertanian, Kehutanan, Perikanan Terhadap Pdrb Di Kabupaten Lamongan. Jurnal Ilmu Ekonomi, 2 (1), 14-25.

Setiawan, A., \& Soelistyo, A. (2017). Analisis Pendapatan Petani Buah Naga di Desa Sambirejo Kecamatan Bangorejo Kabupaten Banyuwangi. JIE Jurnal Ilmu Ekonomi UMM, 1-10.

Silalahi, D., Sitepu, R., \& Tarigan, G. (2014). Analisis Ketahanan Pangan Provinsi Sumatera Utara Dengan Metode Regresi Data Panel, Jurnal Saintia Matematika, 2 (3), 237-251.

Triyanto, J. (2006). Analisis Produksi Padi di Jawa Tengah. Universitas Diponegoro. Universitas Diponegoro. 